\title{
EFFECTS OF DIPOLE MODE AND EL-NINO EVENTS ON CATCHES OF YELLOWFIN TUNA (Thunnus albacares) IN THE EASTERN INDIAN OCEAN OFF WEST JAVA
}

\author{
Khairul Amri' ${ }^{1}$ Ali Suman', Hari Eko Irianto² and Wudianto² \\ ${ }^{1}$ Institute for Marine Fisheries, Muara Baru - Jakarta \\ ${ }^{2}$ Center for Fisheries Management and Conservation, Jakarta \\ Received; March 04-2014 Received in revised from November 30-2015; Accepted December 03-2015 \\ email:kh_amri@yahoo.com
}

\begin{abstract}
The effects of Indian Ocean Dipole Mode and EI Niño-Southern Oscillation events on catches of YellowfinTuna (Thunnus albacares) in the Eastern Indian Ocean (EIO) off Java were evaluated through the use of remotely sensed environmental data (sea surface temperature/SST and chlorophyll-a concentration/SSC) and Yellowfin Tuna catch data. Analyses were conducted for the period of 2003-2012, which included the strong positive dipole mode event in association with weak El-Nino 2006. Yellowfin Tuna catch data were taken from Palabuhanratu landing place and remotely sensed environmental data were taken from MODIS-Aqua sensor. The result showed that regional climate anomaly Indian Ocean Dipole Mode influenced Yellowfin Tuna catch and its composition. The catches per unit effort (CPUE) of Thunnus alabacares in the strong positive dipole mode event in 2006 and weak El-Nino events in 2011 and 2012 was higher. The increase patern of CPUE followed the upwelling process, started from May-June achieved the peak between September-October.Very high increase in CPUE when strong positive dipole mode event (2006) and a weak El-Nino events (2011 and 2012) had a relation with the increase in the distribution of chlorophyll-a indicating an increase in the abundance of phytoplankton (primary productivity) due to upwelling. In contrast, yellowfin tuna CPUE is very low at the La-Nina event (2005), though as the dominant catch when compared to others.
\end{abstract}

\section{KEYWORDS: Indian Ocean Dipole Mode, YellowfinTuna, Eastern Indian Ocean off west Java}

\section{INTRODUCTION}

Eastern Indian Ocean (EIO) is the unique waters because geographically influenced by water masses from the western Indian Ocean and the outflow water masses from the Pacific Ocean. Both of these water masses affect the variability of oceanographic conditions in these areas. In addition, the location of its waters is in the monsoon wind system causing conditions oceanographycally affected by monsoon wind system (Wyrtki, 1961). Winds over the Indonesian maritime continent and the position of the Intertropical Convergence Zone are dominant features of strong monsoon signatures in this area. During the southeast monsoon (May to October), southeasterly winds from Australia generate upwelling along the southern coasts of Java and Bali. Upwelling events led to the concentration of chlorophyll-a increased so that the primary productivity takes place (Wyrtki, 1962; Purba, 1995). Reversed conditions occur during the northwest monsoon (November to April) (Gordon, 2005).

EIO off west Java is rich in fishery resources of tunas species which landed in the Palabuhanratu Fishing Port (Mertha, 2006). The tunas species in this area exploited by using various fishing gears, i.e.long line, purse seinne, gillnet, troll line and pelagic Danish seine.

Variability of water masses in the EIO is very high, associated with the intrusion of water masses from other regions such as the Indonesian Through Flow (ITF), the influence of changes occurred in the monsoon wind system (Wyrtki, 1961; Purba et al., 1997), and is affected by global climate change as and Indian Ocean Dipole Mode (IOD) (Saji et al., 1999; Shinoda et al., 2004). Saji et al. (1999) defines the IOD as a symptom of climate aberrations due to the interaction of the sea and the atmosphere at certain times which shows the pattern of variability of temperature deviations in the western and eastern Indian Ocean with the wind direction and precipitation deviations. Dipole mode structure is characterized by an anomaly sea surface temperature (SST), warmer than normal in the western Indian Ocean and cooler than normal in the eastern Indian Ocean, which is referred to as positive dipole mode event. Reversely the incidence of so-called negative dipole mode event, is characterized by SST warming in the eastern Indian Ocean and the decline of SST in the western Indian Ocean (Vinaychanran et al., 2001). The phenomenon of ENSO or EI Nino Southern Oscillation is the phase difference in air pressure of global sea level between 
Indonesia and Southeast Pacific Ocean (Quin et al., 1978). Both of these climate phenomena directly affect oceanographic conditions in the Indian Ocean and are believed to also affect the distribution and abundance of fish resources, including the tuna species.

Various studies suggest that the distribution and abundance of tuna are influenced by several oceanographic parameters. The variation in water temperature has an important role in determining the spatial distribution of tuna fish (Laevastu \& Rosa, 1963; Squire, 1982). Yellowfin tuna (Thunnus albacares) has spread vertically with thermocline constraint (Longhurst \& Pauly, 1987), while Albakora and Big eyes usually lives in waters below the thermocline layer (Laevastu \& Hayes, 1982).

Most of the research conducted on tuna in the Indian Ocean generally examined the relationship between several oceanographic parameters, particularly the distribution of Bigeye tuna species
(Thunnus obesus), as reported by Mohri \& Nishida (1999), Song et al. (2009), and Song \& Zhou (2010). Therelationship between oceanographic factors dealing with the ENSO climate anomalies is reported by Yoder \& Kennely (2003); Gaol (2003) and Syamsuddin et al.(2013). Meanwhile studies on yellowfin tuna for tuna species has not been widely reported.

This paper aims to examine the influence of climate anomalies (Indian Ocean Dipole Mode) and the El Niño - Southern Oscillation (ENSO) in the Indian Ocean, especially in the eastern part of West Java (EIO off west Java) to Yellowfin tuna (Thunnus albacares) Catches.

\section{MATERIALS AND METHODS}

The study area was located in the EIO, south of west Java, spanning between $100^{\circ}-110 .^{\circ} \mathrm{BT}$ and $7.0^{\circ}$ - $12^{0}$ LS (Figure 1).

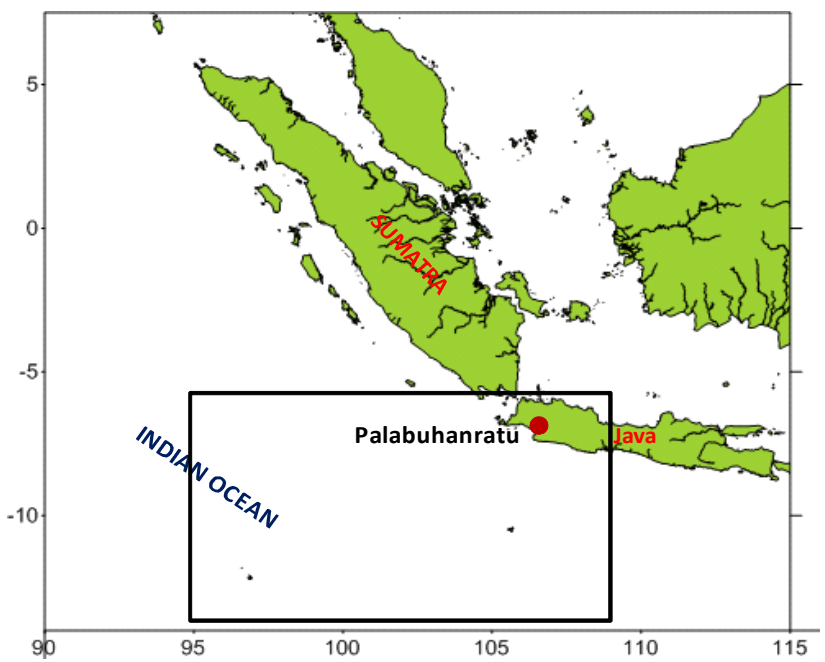

Figure 1. Map of the EIO, with the inset box representing the study area in the West Java.

For this study, we used Yellowfin tuna catches and oceanographic data such as sea surface temperature (Sea Surface Temperature/SST) and chlorophyll-a (Sea Susrface Chlorophyll-a/SSC) satellite remote sensing measurements. Yellowfin tuna catch and oceanographic data used for observation were the 10-year period from 2003 to 2012 . During this period there were IOD and ENSO events, i.e. 2003 (weak positive IOD), 2005 (weak La-Nina), 2006 (strong positive IOD and weak El-Nino), 2007 (weak positive IOD and moderate La-Nina), 2008 (weak positive IOD); 2009 (moderate El-Nino), 2010 (strong La-Nina), 2011 and 2012 (weak El-Nino). From 2006-2008 there was triple consecutive positive IOD events in the year of 2006, 2007 and 2008.
Indications of climate anomalies (IOD and ENSO) was seen from Sea Surface Temperature (SST). SST satellite image used in this study measured the MODIS sensor (Moderate Resolution Imaging Spectroradiometer) satellite Aqua, years 2003-2012 (http://gdata1.sci.gsfc.nasa.gov/). SST estimated using MODIS standard algorithm $11 \mathrm{~lm}$ NLSST Algorithm (http://nasa.gsfc.gov). Chlorophyll-a OC3M allegedly based algorithm (O'Reilly et al., 2000). The data in monthly format with a spatial resolution of 4 $\mathrm{km}$.

Yellowfin tuna catches records were obtained from Nusantara Fishing Port/Pelabuhan Perikanan Nusantara (PPN) Palabuhanratu, West Java. The data 
were obtained is from is landing vessels owned by tuna fishing companies (with longline fishing gear) and individuals or groups of fishermen (with longline fishing gear and troll line). The data include the number of catches per month (in kilograms) by fishing gear, boats and the number of trips per month and locations where operations FADs ships troll line.

The data were analyzed to get catch per trip (CPUE /Catch per Unit Effort) information. Catches and fishing effort data were obtained from different fishing gears (long line and troll line). Standardization (standard long line) done by calculating the Fishing Power Index (FPI) and Standard Effort. The formula used to calculate CPUE is as follows (Gulland, 1982).

CPUE $_{i}=\frac{\text { catch }_{i}}{\text { effort }_{i}} \quad \mathrm{i}=1,2, \ldots, n$

Were:

CPUE $_{i}=$ catch per unit effort by year $\mathrm{i}$ catch $_{\mathrm{i}}=$ catch by year $\mathrm{i}$

effort $_{\mathrm{i}}=$ effort by year $\mathrm{i}$

Descriptive analysis was carried out by comparing the pattern of catches between the years with the IOD and ENSO events on Yellowfin Tuna catches.

\section{RESULTS AND DISCUSSION \\ Results \\ Features of Oceanographic Conditions}

Figure 2 shows the position of fishing ground from troll line and long line who landed their yellowfin tuna catches in Palabuhanratu. Troll line fishing ground is usually close to fish aggregating devices (FADs). Fishing ground pattern is following the monsoon seasons. During the southeast monsoon (Juny-JulyAugust), fishing ground location is shifted a few miles to the east and during the west monsoon (NovemberDecember-January) fishing ground location is shifted a few miles to the west. The shifting position is usually not more than 5 miles from the FADs position.

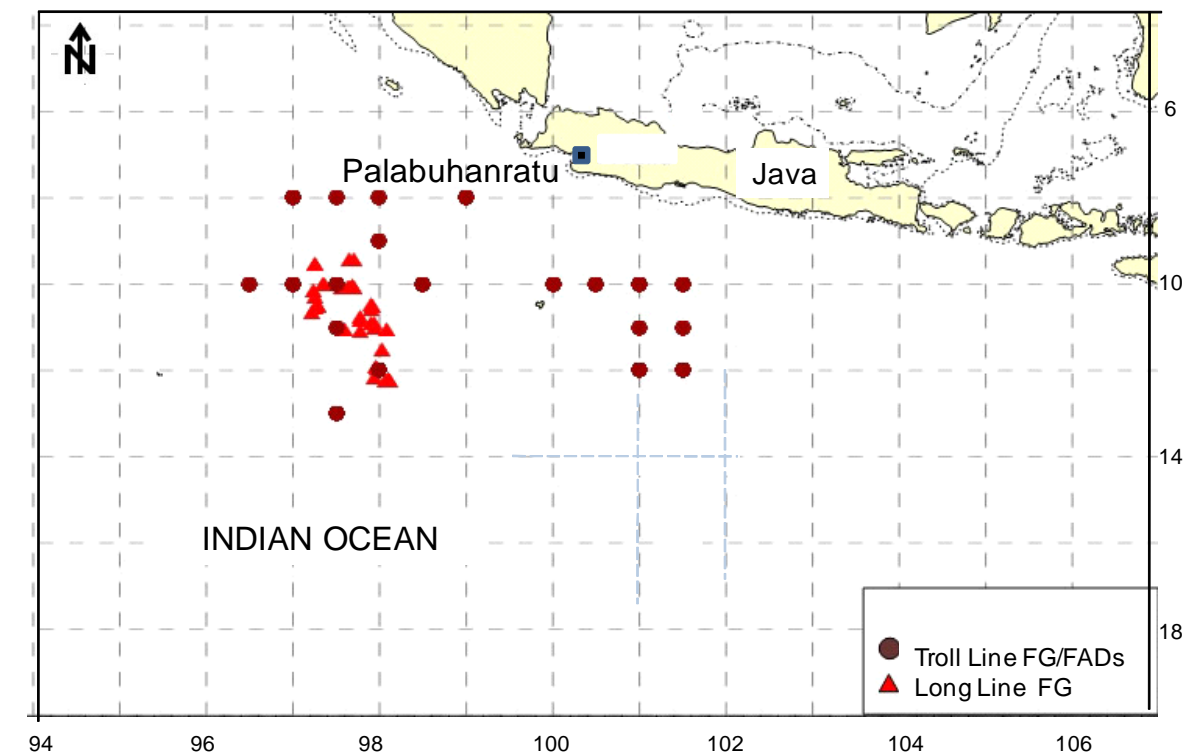

Figure 2. Map of the Fishing Ground Yellowfin Tuna (fishing gear: longline and troll line) in EIO off West Java.

The EIO off west Java has complex dynamic currents and wave systems (Syamsuddin et al., 2012). The dominant current and wave features include (Figure 3): 1) the Indonesian Through ûow (ITF), outûow water from the Paciûc to the Indian Ocean (Molcard et al., 2001; Gordon et al., 2010); 2) the seasonally reversing South Java Current (SJC) along the southern coast of the Indonesian Sea (Sprintall et al., 2010); 3) the Indian Ocean South Equatorial Current (SEC) that ûows from the southern Indian Ocean to an area off southern Java (Zhou et al., 2008); 4) downwelling Indian Ocean Kelvin Waves (IOKWs) that propagate to the east along the coasts of west
Sumatra, Java, and the lesser Sunda islands (Syamsudin et al., 2004); and 5) westward Rossby Waves propagation at $12-15^{\circ} \mathrm{S}$ (Gordon, 2005; Sprintall et al., 2009). Besides these current and wave systems, winds over the Indonesian maritime continent and the position of the Intertropical Convergence Zone are dominant features of strong monsoon signatures. During the southeast monsoon (May to October), southeasterly winds from Australia generate upwelling along the southern coasts of Java and Bali. These conditions are reversed during the northwest monsoon (November to April) (Gordon, 2005). 


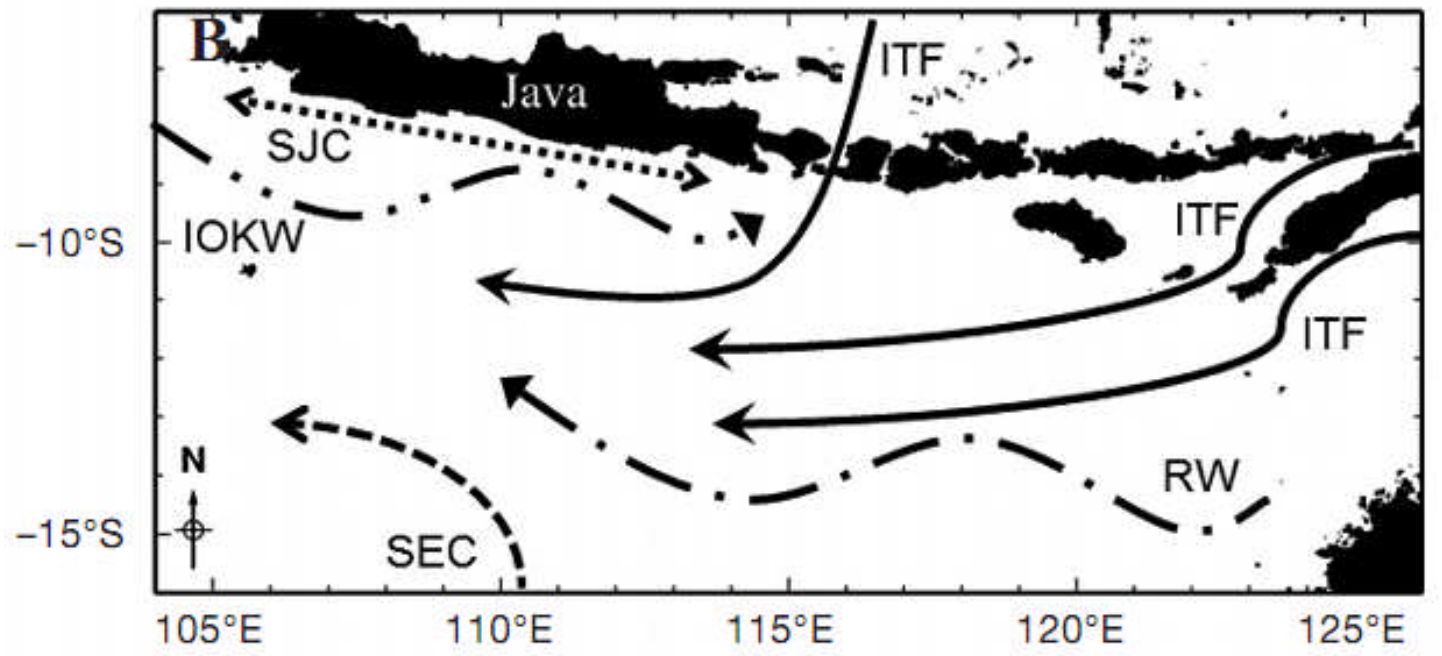

Figure 3. The wave and current systems in the East Indian Ocean off Java are indicated by the dotted line for the South Java Current (SJC), solid lines for the Indonesian Through Flow (ITF), the line with dashes and 2 dots for the Indian Ocean Kelvin Waves (IOKWs), the line with dashes and 1 dot for the Rossby Waves (RWs), and the dashed line for the Indian Ocean South Equatorial Current (SEC) (source: Syamsuddin et al., 2012).

Upwelling in the southern Java - Bali increased in intensity when the climate anomaly and a positive IOD or El - Nino events occured. However, the opposite occurs or negative IOD and La Nina events do not occur in these waters upwelling (Gaol, 2003; Amri et al., 2012). In the event of a positive IOD event, the SPL had negative anomalies (lower than normal) (Saji et al., 1999; Webster et al., 1999) .

Upwelling that occurs when positive IOD events is triggered by the strengthening wind anomalies along the southern coast of Sumatra and Java as well as east winds along the equator. The strengthening winds push water away from the coast or the equator, so that the water masses along the south west coast of Sumatra and Java are vacant. Mass of the surface layer water fills the vacant layer, and the mass of the bottom layer water rises to the surface inducing the occorrence of upwelling. Upwelling brings nutrient rich water mass to the surface, thus increasing the primary productivity, marked by the increase in the distribution of chlorophyll-a (phytoplankton). Generally waters in upwelling sites are abundant fish resources.

Figure 4 shows the Sea Surface Temperature (SST) images EIO waters off west Java. Upwelling with high intensity as indicated by the decrease in SST occurred in 2003 (weak positive IOD), 2006 (strong positive IOD and weak El - Nino), 2007 (weak positive IOD and moderate La - Nina), 2008 (weak positive IOD) and 2009 (moderate El - Nino). In 2011 and 2012 upwelling also occurs with high intensity at which time the El Nino events occur. Highest upwelling intensity as indicated by the low SST area with the most extensive water mass occurred in 2006, during the strong positive IOD by mid-year, followed by a weak El - Nino events at the end of the year. In contrast, during the negative IOD/La - Nina events do not occur in these waters upwelling: 2005 (weak La - Nina) and 2010 (strong La - Nina). In a normal year (2004) upwelling occurs with normal intensity (low).

SST distribution value ranges at the fishing ground of longline and troll linein the southern west Java (Appendix 1) were in 2003: $26.8-29.12^{\circ} \mathrm{C}$ (average 27.91 ${ }^{\circ} \mathrm{C}$ ); $2004: 26.51-29.06{ }^{\circ} \mathrm{C}$ (average $27.88^{\circ} \mathrm{C}$ ); 2005: $27.10-29.92^{\circ} \mathrm{C}$ (average $28.05^{\circ} \mathrm{C}$ ); 2006: 25.30$29.22{ }^{\circ} \mathrm{C}$ (average $27.65^{\circ} \mathrm{C}$ ); $2007: 27.17-29.21^{\circ} \mathrm{C}$ (average $27.97^{\circ} \mathrm{C}$ ); $2008: 26.73-29.07^{\circ} \mathrm{C}$ (average $27.72^{\circ} \mathrm{C}$ ); $2009: 27.02-29.04^{\circ} \mathrm{C}$ (average $28.24^{\circ} \mathrm{C}$ ); 2010: $27.33-30.06^{\circ} \mathrm{C}$ (average $28.65^{\circ} \mathrm{C}$ ); $2010: 25.91$ $-29.00^{\circ} \mathrm{C}$ (average $27.69^{\circ} \mathrm{C}$ ) and $2012: 26.12-28.59^{\circ} \mathrm{C}$ (average $27.52^{\circ} \mathrm{C}$ ). The average value of the distribution of low SST occurred at the positive IOD events (2003, 2006, 2007, and 2008 ) as well as the El - Nino events (2011 and 2012). The average value of the distribution of high SST was in weak and strong La-Nina events (2005 and 2010). Figure 5 displays the average value of the distribution of SST in the southern West Java by IOD and ENSO events. Which the figure shows the average value of the distribution of SST was lowest in the positive IOD event (year 2006: $27.65^{\circ} \mathrm{C}$ ) and EI - Nino event (year $2012: 27.52^{\circ} \mathrm{C}$ ), while the highest SST was in the strong La - Nina events (year 2010: $\left.28.65^{\circ} \mathrm{C}\right)$. 


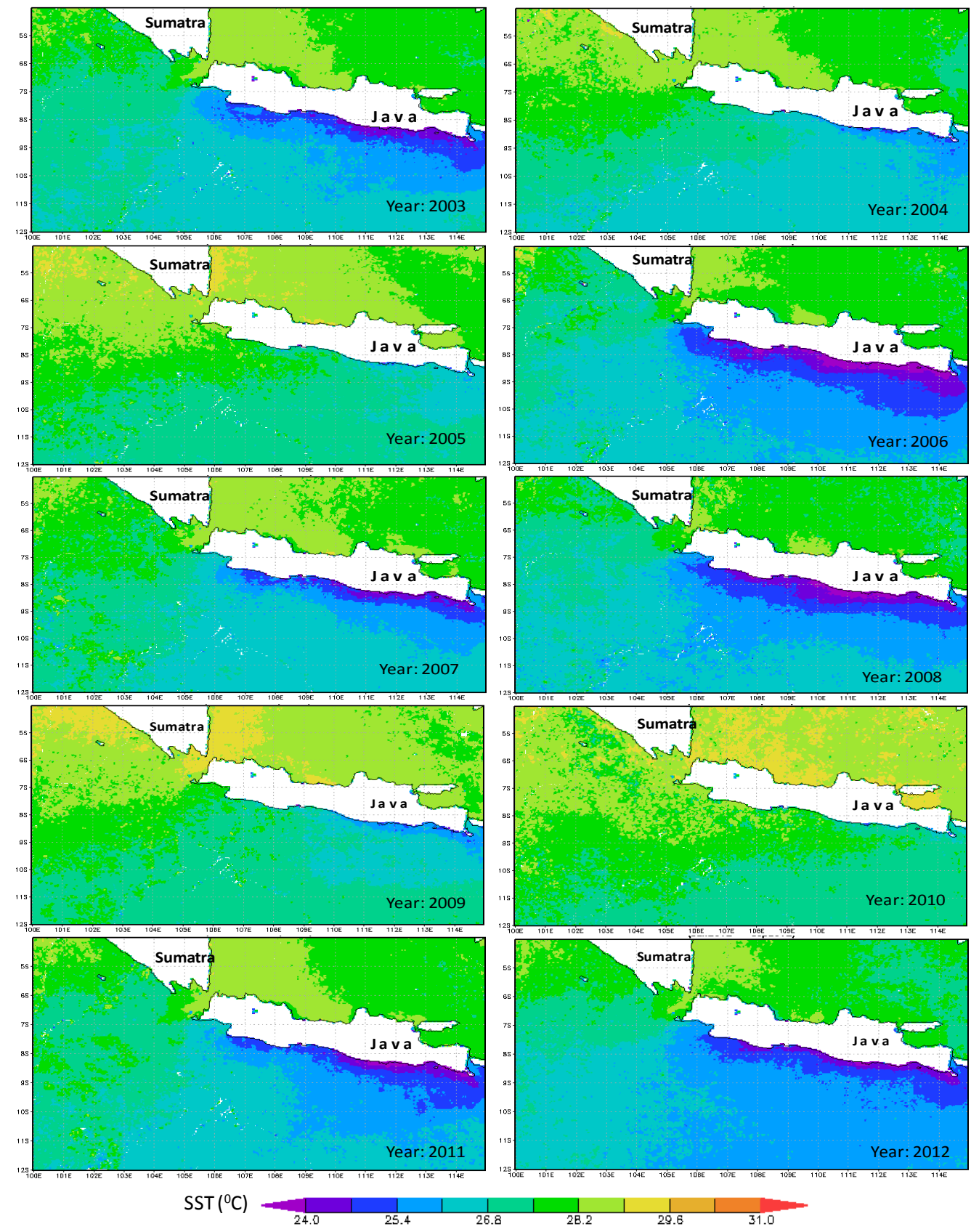

Figure 4. Sea Surface Temperature (SST) images (blue color indicated that upwelling water mass with lower SST on Positive IOD/EI-Nino events)in EIO off West Java.

Annualy average SST by phenomenon $\left({ }^{\circ} \mathrm{C}\right)$

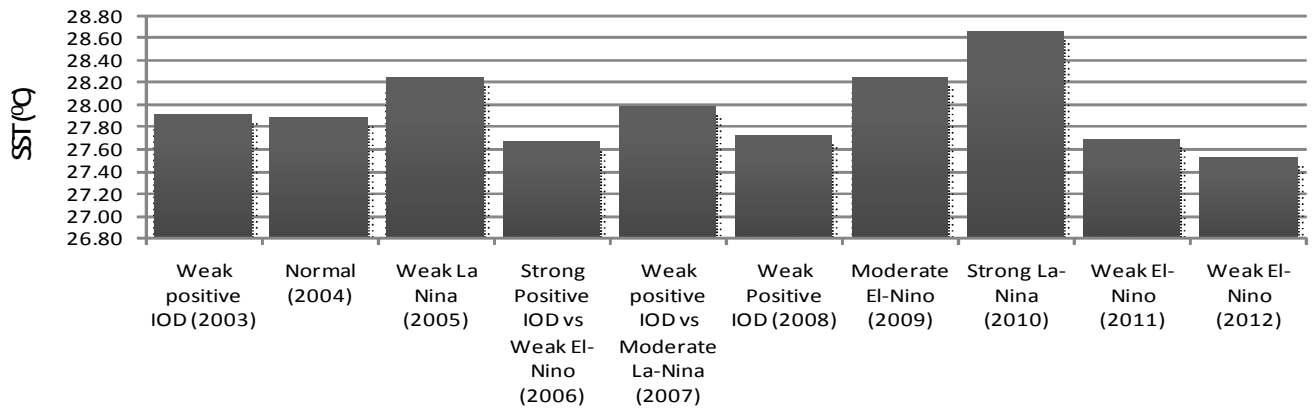

Figure 5. Annualy average of SST by phenomenon in EIO off west Java 2003-2012. 
Figure 6 displays the image of the surface distribution of chlorophyll-a (Sea Surface Chlorophyll / SSC images) EIO waters off west Java. Increase in the value of the distribution of chlorophyll-a with high spread value and distribution of a wide area occurred in the years of intensive upwelling, i.e. the positive phase of the IOD events $(2003,2006,2007$, and 2008) as well as the El-Nino events (2009, 2011 and 2012).
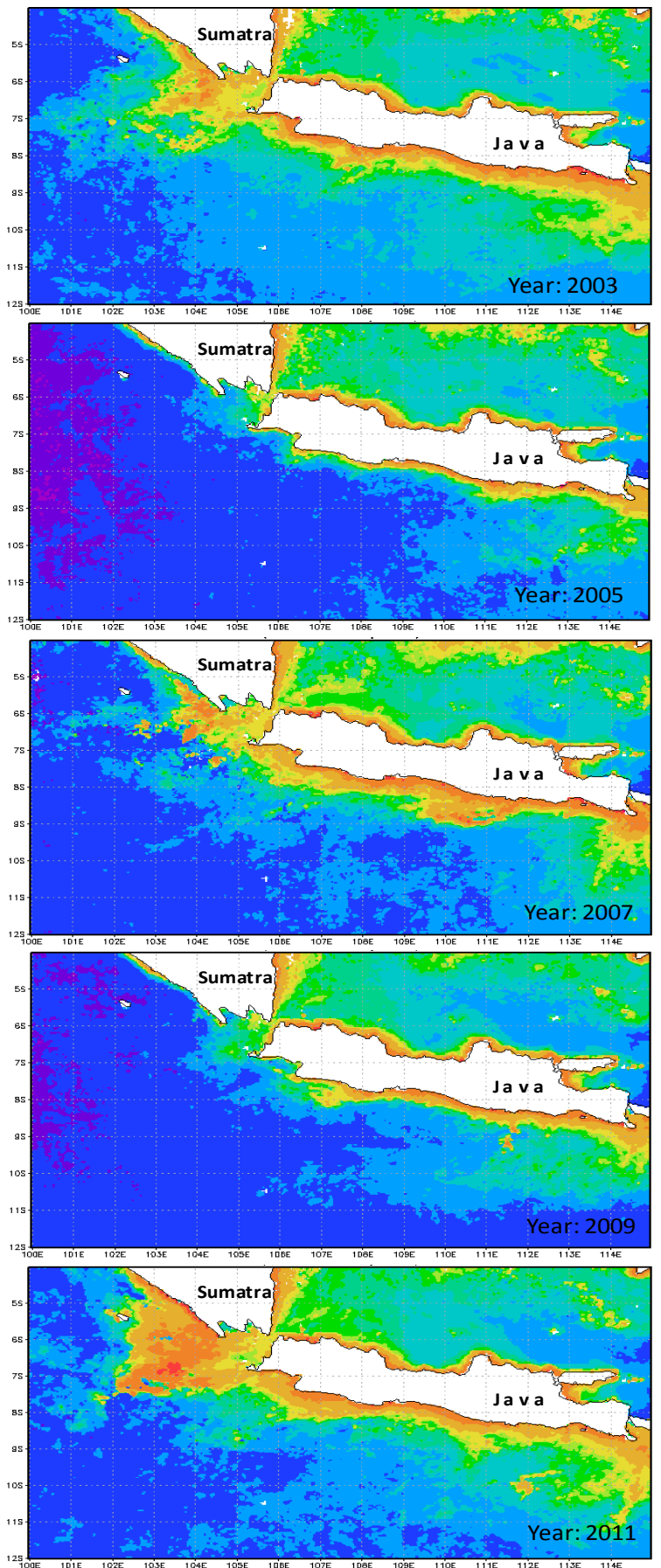

Distribution of chlorophyll-a value of the lowest was found in the La-Nina events (2005 and 2010). Value distribution of chlorophyll-a in the La-Nina events was lower than the normal phase (2004). The location of the increased value of the distribution of chlorophyll-a was identical to the location of the SPL reduction proving that enrichment of chlorophyll-a occurred due to upwelling events.
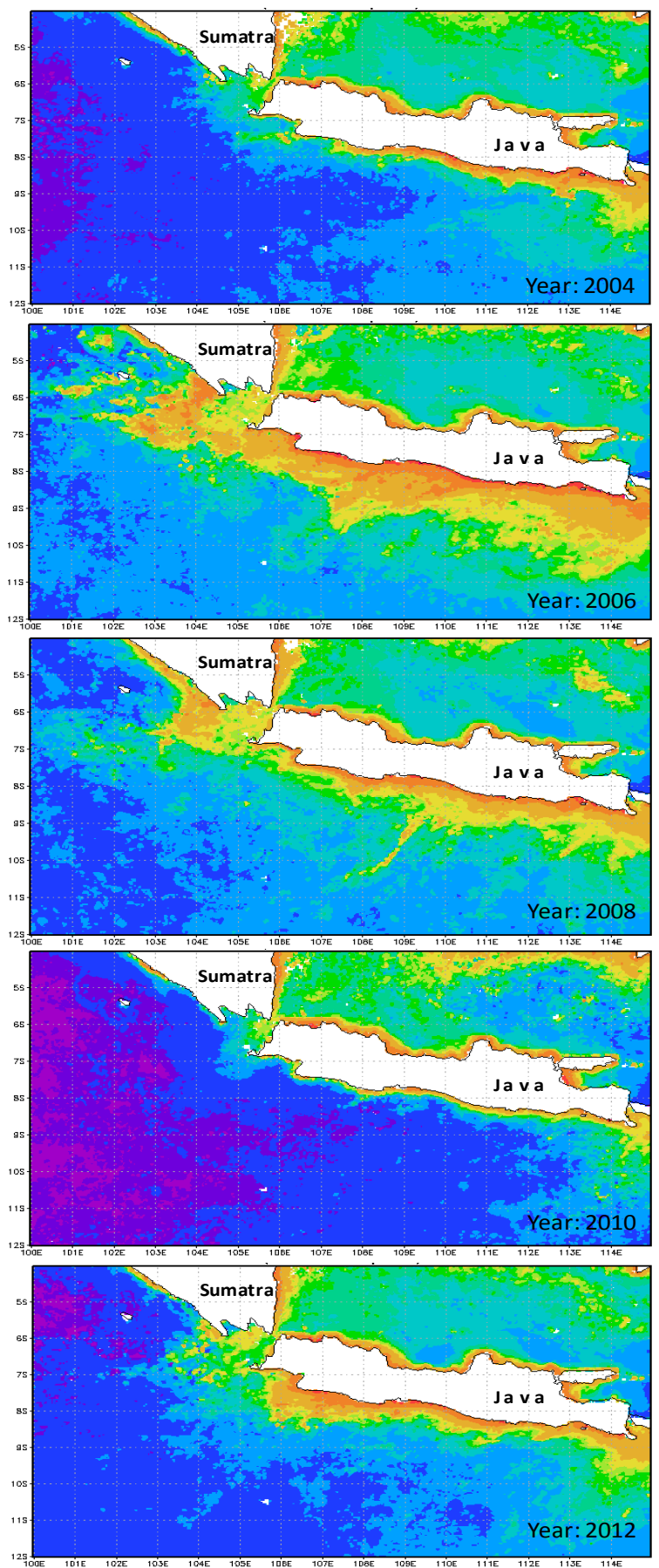

$\mathrm{SSC}\left(\mathrm{mg} / \mathrm{m}^{3}\right)$

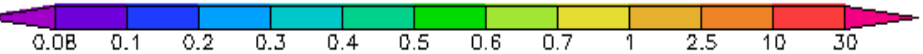

Figure 6. Sea Surface Chlorophyll-a images (yellow and red color indicated that higher chlorophyll-a concentration as effect of upwelling process) in EIO off west Java. 
SSC spread value ranges in the location of fishing ground troll line and longline the waters off southern west Java (Appendix 2) were in 2003: 0.0874-0.2421 $\mathrm{mg} / \mathrm{m}^{3}$ (average $0.1434 \mathrm{mg} / \mathrm{m}^{3}$ ); 2004: 0.0913-0.2155 $\mathrm{mg} / \mathrm{m}^{3}$ (average $0.131817 \mathrm{mg} / \mathrm{m}^{3}$ ); 2005:0.0846 $0.1955 \mathrm{mg} / \mathrm{m}^{3}$ (average $0.1282 \mathrm{mg} / \mathrm{m}^{3}$ ); 2006 :t 0.0956 $-0.2909 \mathrm{mg} / \mathrm{m}^{3}$ (average $\left.0.1949 \mathrm{mg} / \mathrm{m}^{3}\right) ; 2007: 0.1050$ - $0.2314 \mathrm{mg} / \mathrm{m}^{3}$ (average $0.1594 \mathrm{mg} / \mathrm{m}^{3}$ ); 2008: 0.0911 - $0.2577 \mathrm{mg} / \mathrm{m}^{3}$ (average $0.1538 \mathrm{mg} / \mathrm{m}^{3}$ ); 2009: 0.0799$0.1955 \mathrm{mg} / \mathrm{m}^{3}$ (average $0.1266 \mathrm{mg} / \mathrm{m}^{3}$ ); 2010: 0.0890 - $0.1318 \mathrm{mg} / \mathrm{m}^{3}$ (average $\left.0.1045 \mathrm{mg} / \mathrm{m}^{3}\right) ; 2011: 0.1000$ - $0.2310 \mathrm{mg} / \mathrm{m}^{3}$ (average $0.1526 \mathrm{mg} / \mathrm{m}^{3}$ ), and 2012 : $0.0890-0.1818 \mathrm{mg} / \mathrm{m}^{3}$ (average $0.1253 \mathrm{mg} / \mathrm{m}^{3}$ ).

The average value of the distribution of SSC on positive IOD events $(2003,2006,2007$ dan 2008) is simirality with the El-Nino events (2011 and 2012). Average spread value was lowest in the weak SSC and strong El - Nino events (2005 and 2010). Figure 7 displays the average value of the distribution of SSC in southern west Java by IOD and ENSO events .

\section{Catch Rates of Yellowfin Tuna}

Of the total fish landed by fishers in Palabuhanratu, around $22 \%$ were other types of tuna (Yellowfin, Bigeye and Albacora). Skipjact tuna occupied portions $8 \%$ and neritic tuna (Kawakawa, bullet tuna,longtail tuna and frigate tuna) reached $7 \%$. The largest catch proportion of $64 \%$ was mostly small demersal fish and some small pelagic fish (Figure 8).

Annualy average SSC by phenomenon $\left(\mathrm{mg} / \mathrm{m}^{3}\right)$

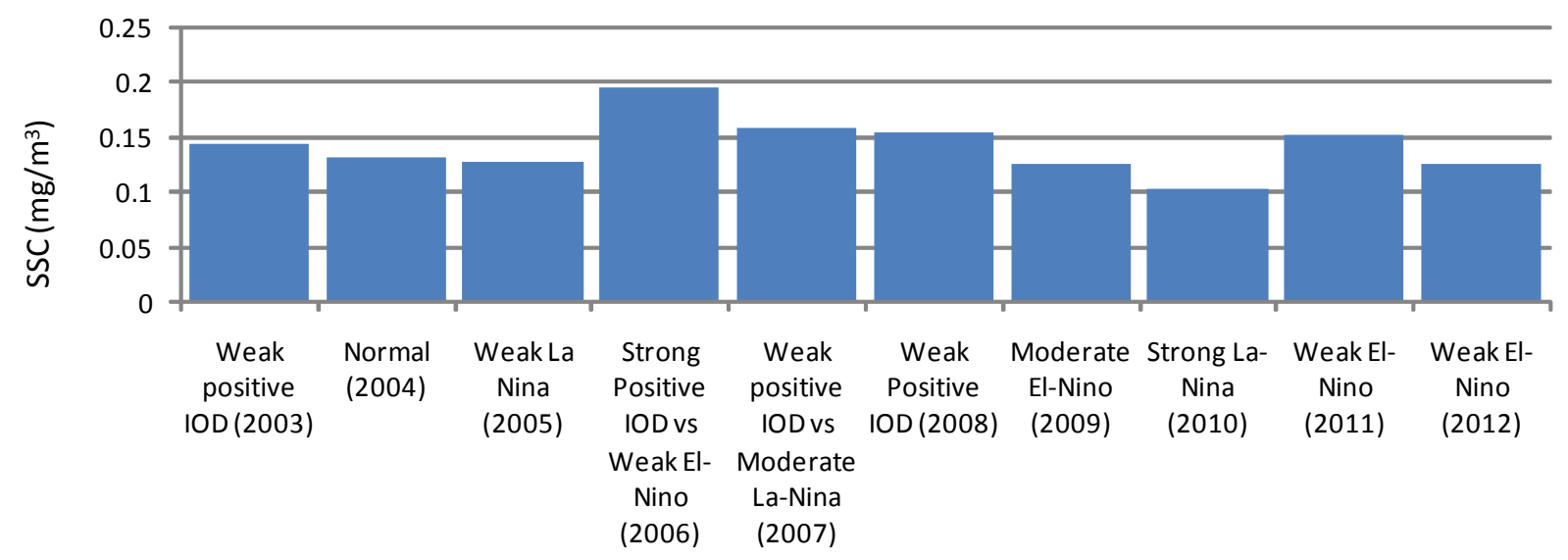

Figure 7. Annualy average of SSC in EIO off west Java by phenomenon 2003-2012.

Average of Total Landing Catch (2003-2012

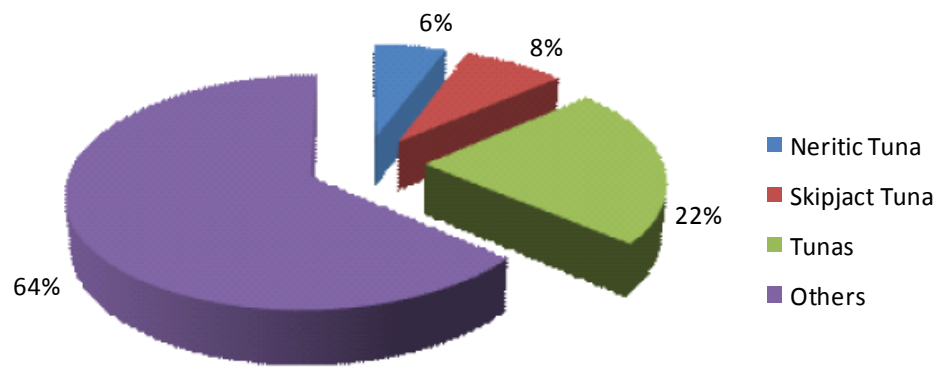

Figure 8. Catch composition (all speciess) were landed Palabuhanratu 2003-2012.

Since 2003, data recording tuna catches are separated into species, i.e.Yellowfin tuna (Thunnus albacares), Bigeye tuna (Thunnus obesus) and Albacora (Thunnus alalunga). Bigeye tuna is the largest catch which is approximately $50 \%$ of the total tuna catch. Yellowfin tuna and Albacore catches occupyf $39 \%$ and $11 \%$ respectively (Figure 9 ).
Yellowfin tuna landed in Palabuhanratu was generally caught using longline, troll line, gillnet, seine and pelagic danish. Dominant fishing gear for yellowfin tuna is a long line approaching $70 \%$ of total yellowfin tuna catch, followed by troll line $(22 \%)$ and gill net $8 \%$ (Figure 10). Payang catch is relatively small, because the operational areas were close to the coast. 


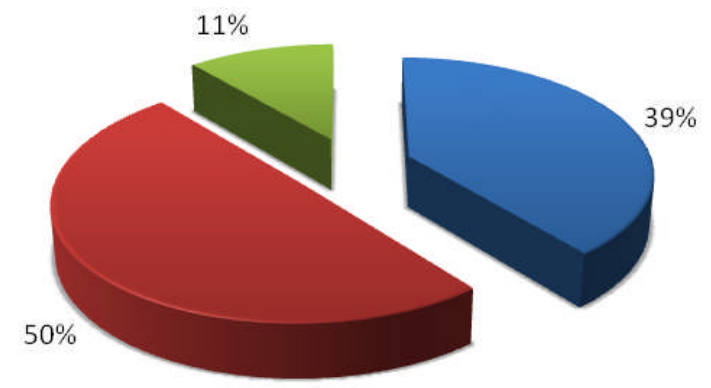

$\square$ Yellow Fin Tuna

Big Eye Tuna

$\square$ Albacora Tuna

Figure 9. Catch composition of tunas landed in Palabuhanratu 2003-2012.

Catch Procentage by Gear (2003-2012)

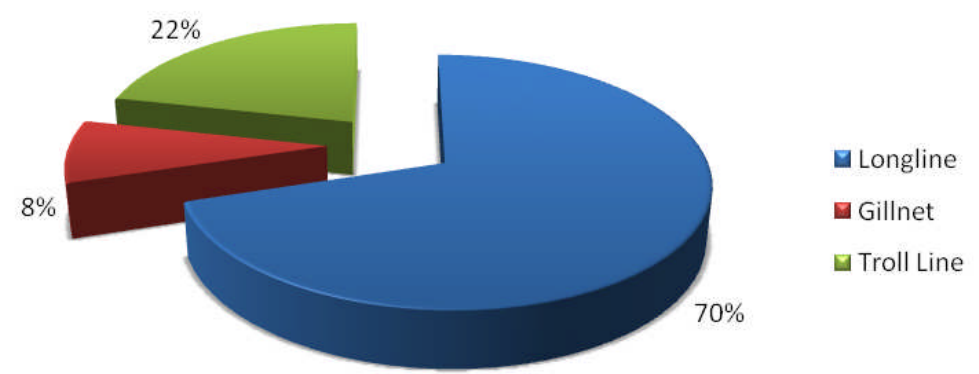

Figure 10. Catch Composition of Yellowfin tuna by Gears.

Total annual yellowfin tuna catch during the period of 2003-2012 is shown in Figure 11. High catches were noted in 2005 ( 1,495 tons), 2010 (1,718 tonnes) and 2012 ( 1,675 tons). The lowest catch was occurred in 2003 (178 tons).

Number of trip per month with most observation in Palabuhanratu, particularly for: longline, gillnet and troll lineis shown in Figure $12(\mathrm{~A}$ and $\mathrm{B})$. The highest total trip took place in 2007 and 2010, i.e. 2,789 trips and 3,056 trips respectively. The lowest trip was noted in 2004, i.e. 956 trips (APPENDIX 3). The highest and the lowest longline trips were identifiedin 2007 (1,611 trips) 2003 (164 trips) respectively. The highest and the lowest gillnet trips were occurred in 2005 ( 1,082 trips) and in 2010 (52 trips) respectively. Trips troll line was The highest troll line trip was in 2010 (1,927 trips) and the lowest was in 2005 (188 trips). As seen in Figure 12, the trips of troll show an increasing trend from 2009.

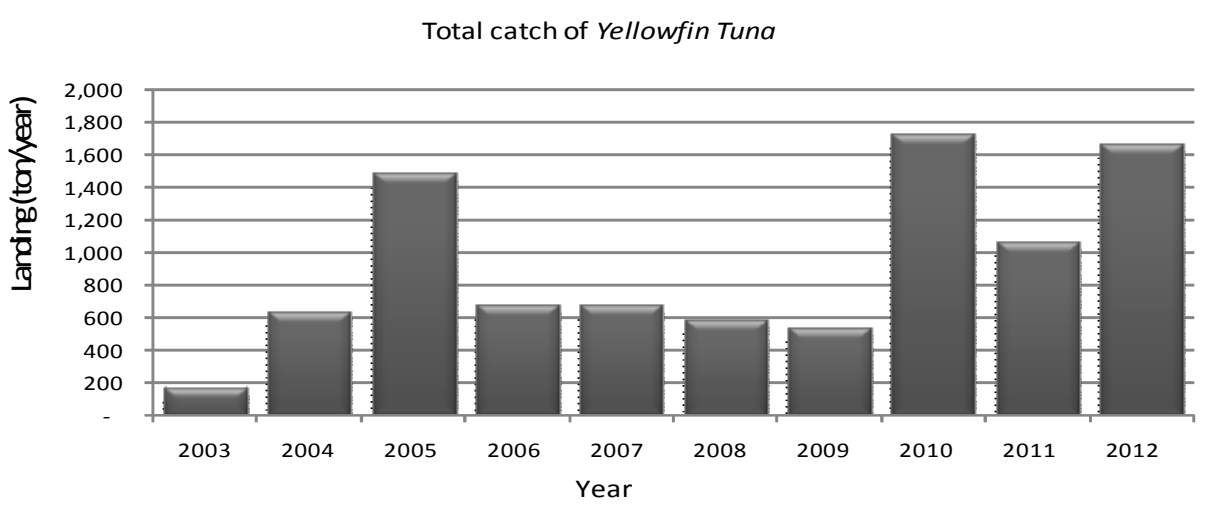

Figure 11. Annualy total catch of Yellowfin Tuna in the period of 2003-2012. 
(A)

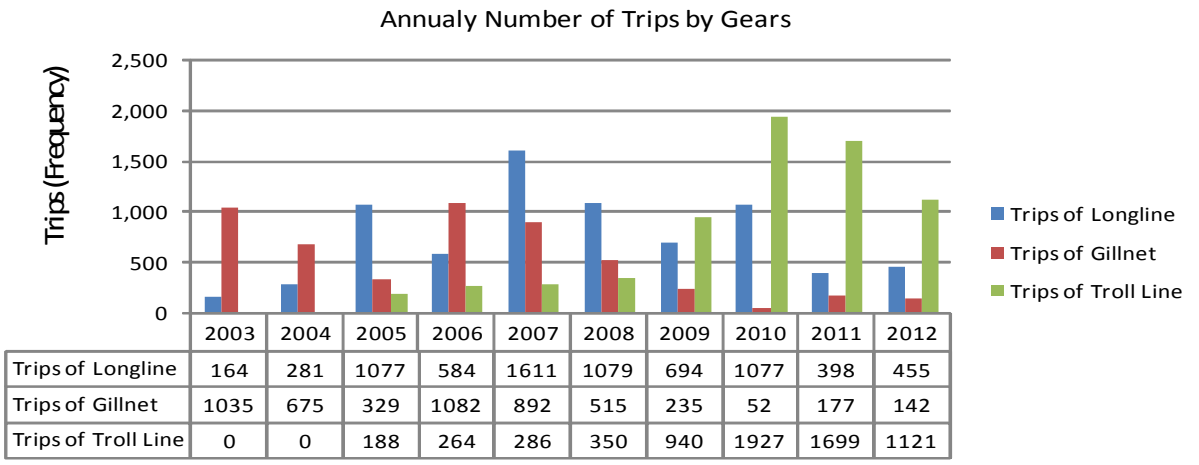

(B)

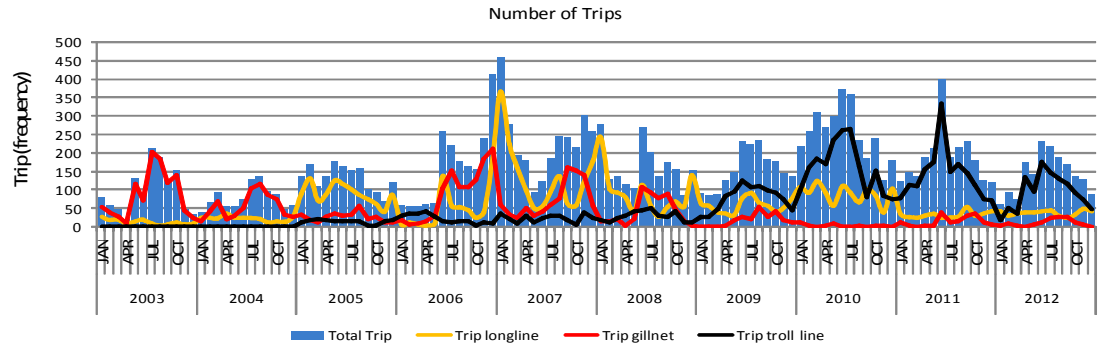

Figure 12. Annualy total trips (above) and monthly trips (below) by fishing gears in the period of 2003-2012.

\section{Catch Per Unit Effort (CPUE) of Yellowfin Tuna}

Catch per Unit Effort (CPUE) of Yellowfin Tuna from 2003 to 2012 is shown in Figure 13. The highest CPUE for yellowfin tuna was occurred in 2006 when the strong positive IOD event in 2011 and 2012 as well as a weak El-Nino events took place. The lowest CPUE was occurred in 2005 in accordance with weak La-Nina event.

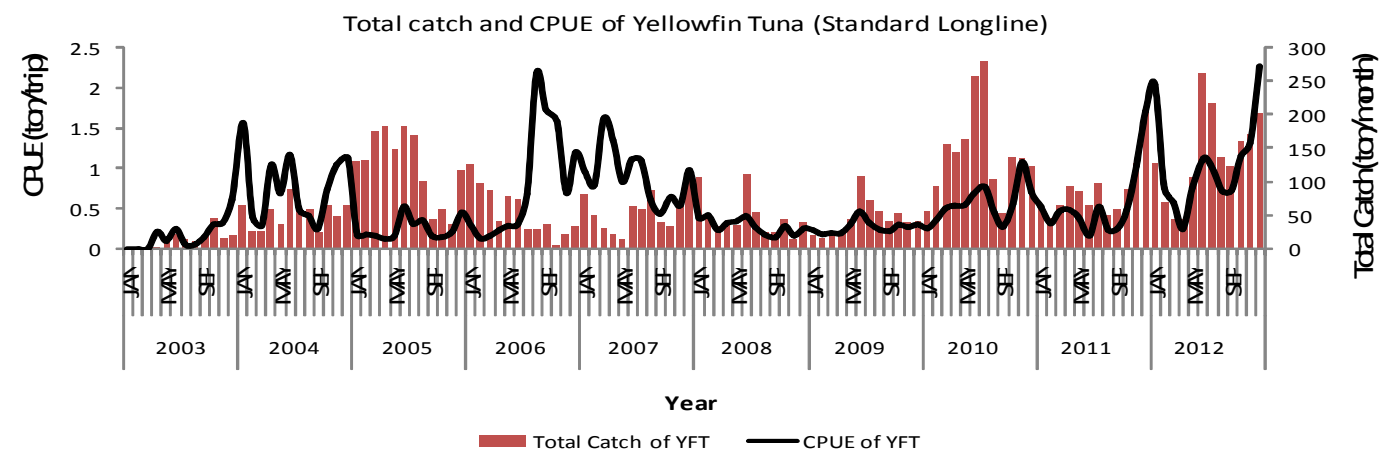

Figure 13. Monthly CPUE of Yellowfin Tuna (standard effort using long line) overlain with total catch 20032012.

\section{Discussion}

Figure 14 displays the temporal variability of SST and SSC/Chlorophyll-a in the EIO off west Java overlain with inter-annual indices (DMI index and NINO 3.4 index). At the time when a strong positive IOD associated with weak El-Nino event in 2006 has caused a decline in the average value of the distribution of SST (around $25^{\circ} \mathrm{C}$ ), this indicates a highly intensity of upwelling. As the positive impact of the upwelling process, at that time an increase in the value of the distribution of chlorophyll-a $\left(0.35 \mathrm{mg} / \mathrm{m}^{3}\right)$ was observed, which indicates an increase in marine primary productivity. The same phenomena with a lower intensity also occurred in 2011 and 2012 during a weak El-Nino event. Conversely, during weak LaNina event in2005 and the strong La-Nina event in 2010) the average value of the distribution of SST was much higher than normal $\left(>29^{\circ} \mathrm{C}\right)$ and in the same period the average value of the distribution of chlorophyll-a was very low $\left(<0.1 \mathrm{mg} / \mathrm{m}^{3}\right)$. 

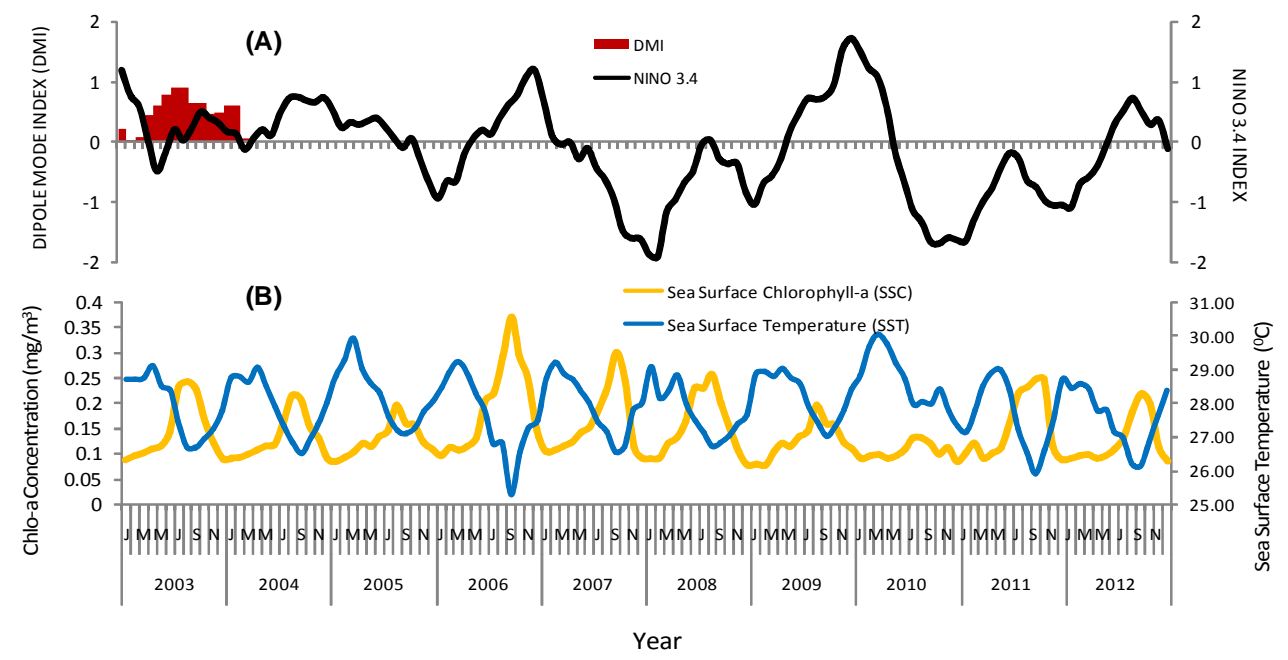

Figure 14. Temporal variability of SST (blue line) and SSC/chlorophyll-a (yellow line) in the Eastern Indian Ocean off West Java), overlain with inter-annual indices, DMI index (shaded in magenta) and NINO 3.4 index (black line).

The average value of the very low SST distribution in 2006 was happened becauseit took place in the middle of strong positive IOD years and at the end of the year followed by weak El-Nino event. Of SST and SSC imagery visible upwelling water masses were characterized by low SST and high spread quite widely chlorophyll-a. Indication of intense upwelling at that time can be seen from the thermocline profile measurements EIO buoy in the waters off the west Java as shown in Figure 15. As seen on the chart of the vertically sea temperature distribution,thermocline layer depletion occurs from June until the end of the year (November), which indicates that the thermocline layer water masses were in the EIO and then pushed to the surface layer, due to the upwelling of water masses encouragement.
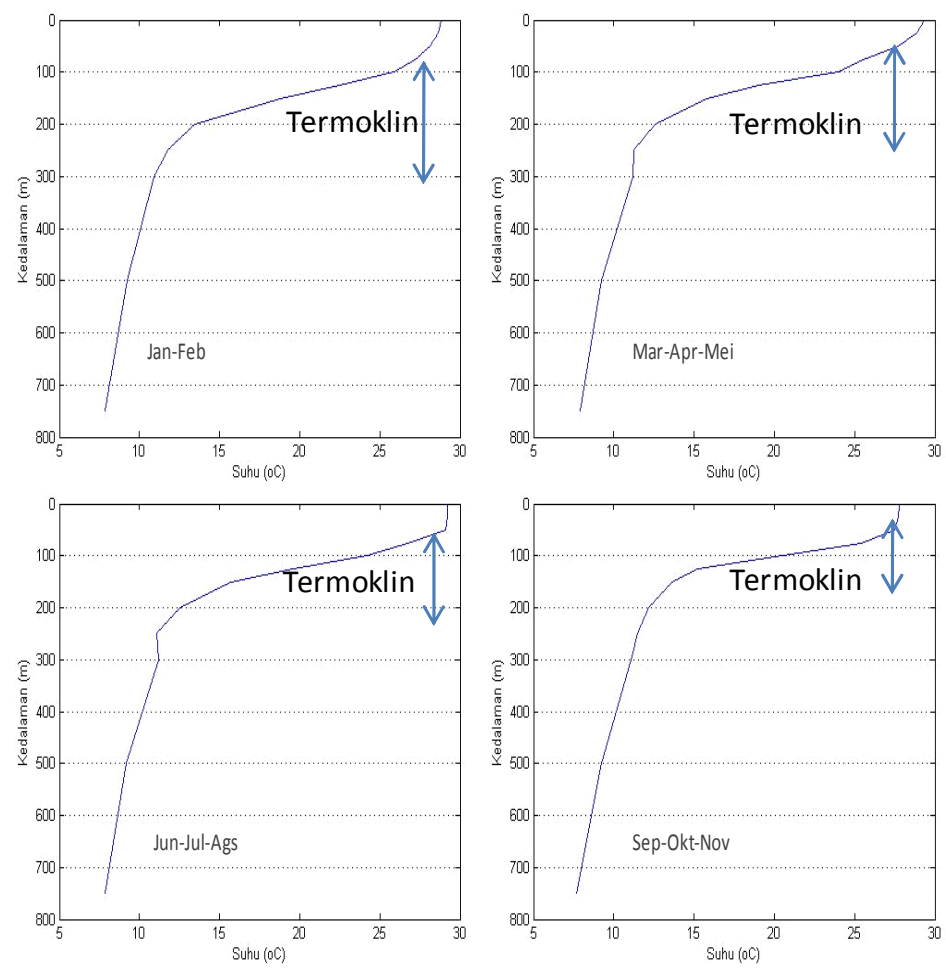

Figure 15. The vertically distribution of sea temperature according to the monsoon in Eastern Indian Ocean taken from buoys instrument data at the strong positive IODM event associated with a low EI Niño event 2006). 
CPUE of yellowfin tuna suggests that the positive IOD events $(2003,2006,2007,2008)$ and EI - Nino events $(2011,2012)$ shows that the increase in CPUE lasts from mid -year until the end of the year (Figure 16). Such pattern is identical to the weakening pattern indicating the ongoing SST upwelling followed by an increase in the value of the distribution of chlorophylla. The linkage pattern between distribution of tuna and oceanographic conditions as described Laevastu and Rosa (1963), Squire (1982) suggest sthat variations in water temperature has an important role in determining the spatial distribution of tuna.

Very high increase in CPUE when strong positive IOD event (2006) and a weak El - Nino events (2011 and 2012) also allegedly associated with an increase in the distribution of chlorophyll-a value reflecting an increase in the abundance of phytoplankton (primary productivity). That condition will encourage yellowfin tuna to migrate to the site associated with the availability of food. Further more, depletion of the thermocline layer pushed to the surface layer, closer to yellowfin tuna as a species living in between the epipelagis - mesopelagis layers, where the fishing gears such as longline, troll line and gillnet operate. Therefore, according to that phenomena the fish abundance is characterized by increasing CPUE. This condition is consistent with Longhurst and Pauly (1987) informing that the type of yellowfin tuna has spread vertically limited by the depth of thermocline layer.
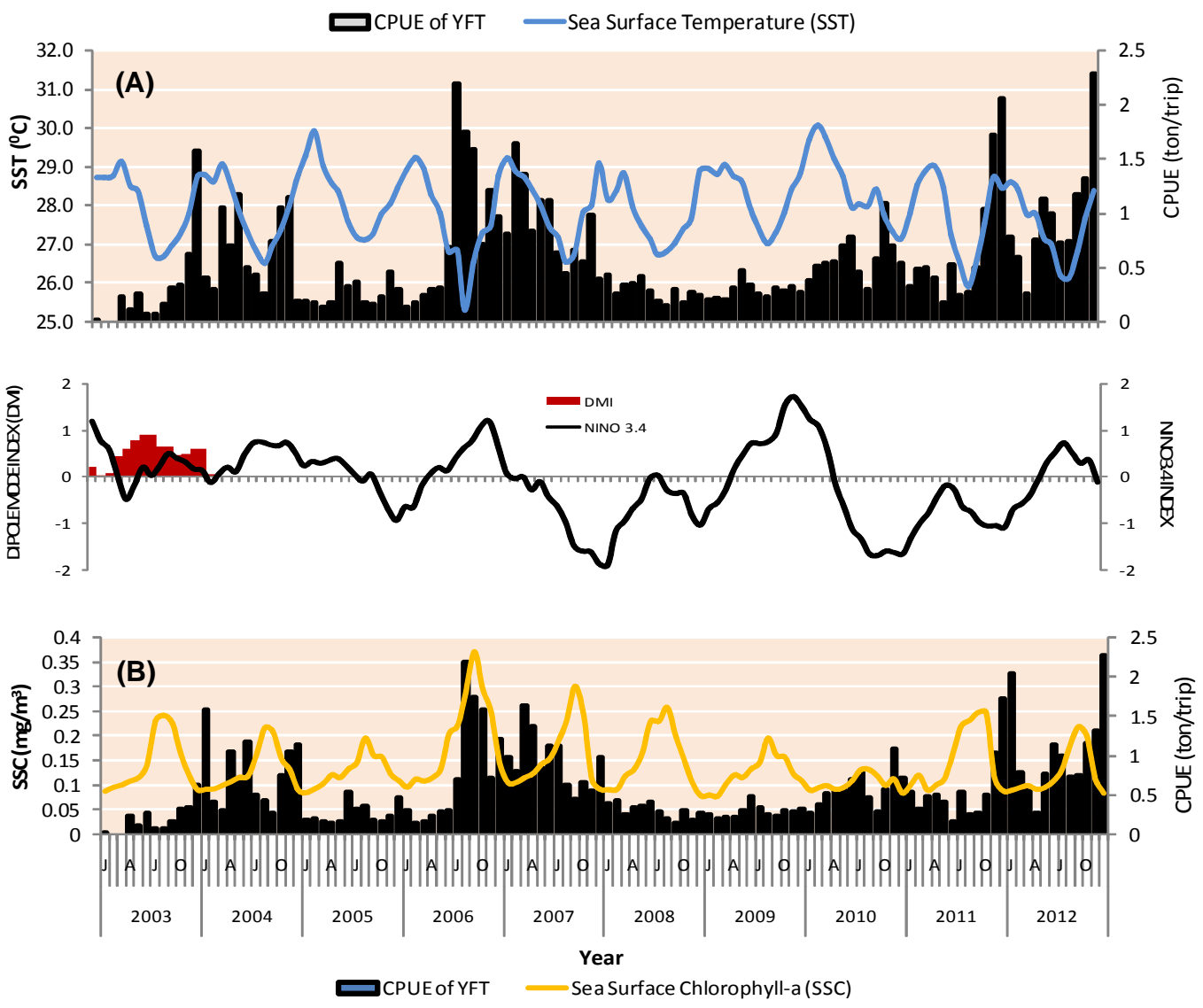

Figure 16. Correlation of SST (above) and SSC (below) with CPUE of Yellowfin Tuna.

Analysis of catch composition per year (Figure 17) revealed that yellowfin tuna caught by fishers in Palabuhanratu was predominant species during normal climatic conditions in 2004 (80.8\%) and weak La-Nina event in 2005 (78.2\%). The proportion of yellowfin tuna reached up to $48.99 \%$ in 2006 when strong positive IOD and weak El-Nino occurred. In the years assoociated with the occurrence of weak positive IOD and El-Nino event, the composition of yellowfin tuna catches was ranging between $29 \%$ and $33 \%$, in which the predominant species in this event was bigeye tuna (51-69\%). While, according to the observations in Palabuhanratu during 2004-2012, albacora was caught in a small percentage (1-14\%). 


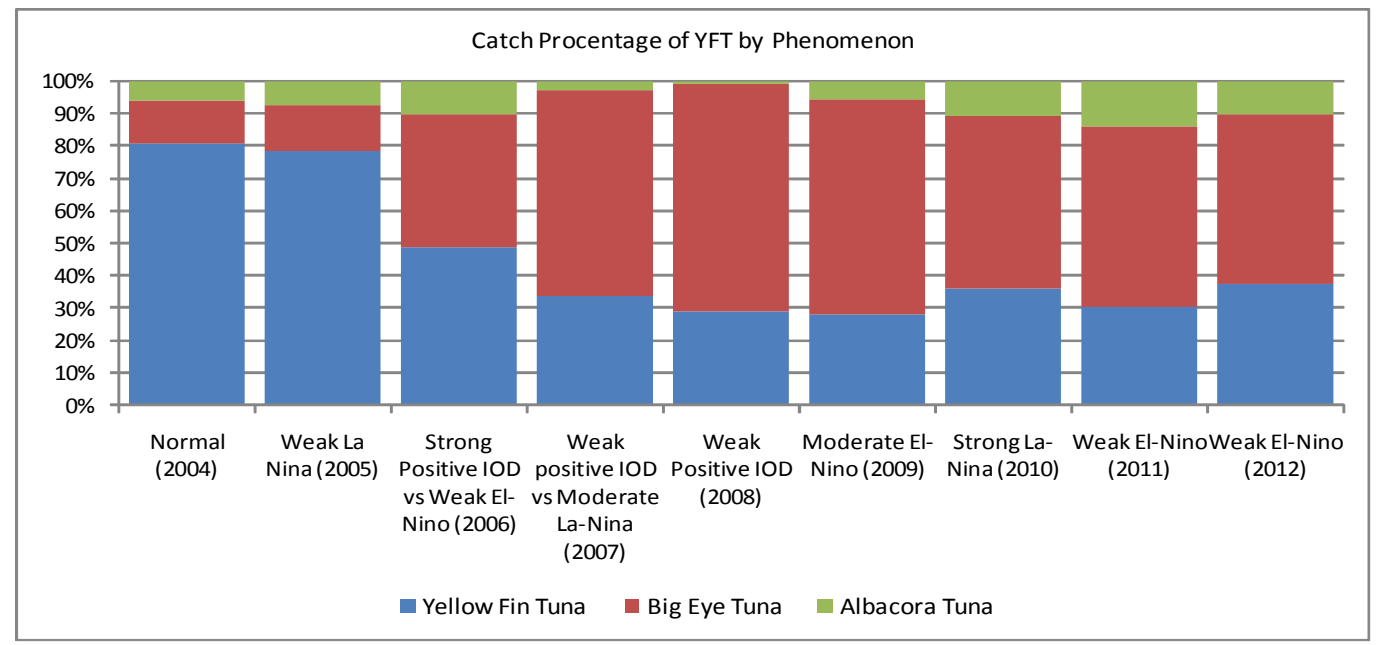

Figure 17. Catch composition (\%) of tuna in Palabuhanratu during period of 2003-2012.

\section{CONCLUSION}

This study revealed the indication of the influence of regional climate anomalies Indian Ocean Dipole Mode (IOD) and EI Niño - Southern Oscillation (ENSO) events on oceanographic conditions (SST and SSC) in the waters of the Eastern Indian Ocean (EIO) off west Java. Changes in oceanographic conditions in the event of climate anomalies influenced the catch of Yellowfin tuna and its composition. The CPUE of Yellowfin tuna in the strong positive dipole mode and a weak El - Nino was higher. The increase of CPUE followed pattern of the upwelling process, started from May - June and get the peak between September and October. Very high increase of in CPUE when strong positive dipole mode and a weak El - Nino was suspected to be related to the increase of the distribution of chlorophyll -a due to upwelling. In contrast, yellowfin tuna CPUE is very low during the La - Nina event eventhough still as predominant catch. Further investigations into the prediction of fishing ground locations of yellowfin tuna through the use of long - term, historical time series of environmental conditions are recommended for better understanding the effects of climate variability.

\section{ACKNOWLEDGEMENTS}

The authors thank the reviewers for their valuable and constructive comments. The access to GES-DISC Interactive Online Visualization and Analysis Infrastructure (GIOVANNI), were greatly appreciated. Thanks are also due to PPN Palabuhanratu official staf for providing tunas catch data.

\section{REFERENCES}

Amri, K., D. Manurung, J.L. Gaol \& M.S. Baskoro. 2012. Chlorophyll-a Variability along Southern Coast of Sumatera and West Java during Positive Phase of Indian Ocean Dipole Mode (IODM). Jurnal Kelautan Nasional. Vol. 7 No.1.Research and Development Center for Marine and Fisheries Technology, Agency for Marine and Fisheries Research.Ministry of Marine and Fisheries Affairs.51-69.

Anonimous. 2013. Final Report 2012. Reserach of Tunas Fisheries Characteristics in Indian Ocean Waters. Tuna Fisheries Reserach Station.Bali. Agency for Marine and Fisheries Research. Ministry of Marine and Fisheries.

Gaol, J.L. 2003. Assessment of the Eastern Indian Ocean Oceanographic Characteristics Derived from Multi Sensor Satellite Imagery and Its Relationship with the Bigeye Tuna (Thunnus obesus) Catch. Disertation. 231 pp. Bogor Agricultural University. Bogor.

Gordon, A., J. Sprintall, V.H.M. Aken, R.D. Susanto, S. Wijffels, R. Molcard, A. Fûeld, W. Pranowo \& S. Wirasantosa. 2010. The Indonesian throughûow during 2004-2006 as observed by the INSTANT program. Dyn. Atmos. Oceans 50:115128.

Gordon, A.L. 2005. Oceanography of the Indonesian seas and their throughûow. Oceanography 18 (4):13-26.

Laevastu \& Hayes. 1982. Fisheries Oceanography and Ecology. Fishing News Books Ltd. Farnham, Surrey, England. 239 pp. 
Longhurst \& Pauly, 1987.Ecology of Tropical Ocean.ICLARM Contribution No. 389.Academic Press, Inc. 407 pp.

Mertha, I.G.S., Moch. Nurhuda \& A. Nasrullah. 2006. (In Indonesian). The development of tuna fishery of Pelabuhan Ratu. J. Lit. Perikan. Ind, Vol.12 (3): 156-167.

Mohri, M \& T. Nishida. 1999. Distribution of bigeye tuna (Thunnus obesus) and its relationship to the environmental conditions in the Indian Ocean based on the Japanese longline ûsheries information. IOTC Proceedings 2: 221-230.

Molcard, R., M. Fieux, \& F. Syamsudin. 2001. The throughflow within Ombai Strait. Deep-Sea Res. I Oceanogr. Res. Pap. 48: 1237-1253.

Purba, M. 1995. Evidence of Upwelling and its Generation Stage off Southern West Jawa During Souteast Monsoon. Bul. ITK Maritek 5 (1): 21 -39.

Purba, M., I.N.M. Natih \& Y. Naulita. 1997. (In Indonesian). Charateristic and Circulation of Water Mass in the South Java-Sumbawa, 5 March-2 April and 23 August-30 September, 1990. Laporan Penelitian. Fakultas Perikanan IPB-BPP Teknologi. Bogor.

Quinn, W.H., D.O. Zopf, K.S. Short \& R.T.W. Kuo Yang. 1978. Historical Trends and Statistics of the Southern Oscilation, El Nino and Indonesian Droughts. Fishery Bulletin.

Saji, N.H., B.N. Goswami, P.N. Vinayachandran \& T. Yamagata. 1999. A Dipole Mode in the Tropical Indian Ocean. Nature, 401:360-363.

Shinoda, T., Harry. H. Hendon \& M. A. Alexander. 2004. Surface and Subsurface Dipole Variability in The Indian Ocean and Its Relation with ENSO. Deep Sea Res I. 51: 619-635.

Song, L \& Y. Zhou. 2010. Developing an integrated habitat index for bigeye tuna (Thunnus obesus) in the Indian Ocean based on longline ûsheries data. Fish. Res. 105:63-74.

Song, L., J. Zhou, Y. Zhou, T. Nishida, W. Jiang \& J. Wang. 2009. Environmental preferences of bigeye tuna, Thunnus obesus, in the Indian Ocean: an application to a longline ûshery. Environ. Biol. Fishes 85:153-171.
Sprintall, J., S. E. Wijffels, R. Molcard \& I. Jaya. 2009. Direct estimates of the Indonesian Throughflow entering the Indian Ocean: 2004-2006. J. Geophys. Res. (C Oceans) 114:1-19.2010.Direct evidence of the South Java Current system in Ombai Strait.Dyn. Atmos. Oceans 50:140-156.

Squire, J.L. 1991. Relative abundance of pelagic resources utilized by the California purse-seine fishery: result of an airborne monitoring program, 1962-90. Fish Bull. 91 (2): 348-361.

Syamsuddin, M.L. Sei-IchiSaitoh, Toru Hirawake, Samsul Bachri Agung \& B. Harto. 2012. Effects of El Niño-Southern Oscillation events on catches of Bigeye Tuna (Thunnus obesus) in the Eastern Indian Ocean off Java.

Syamsudin, F., A. Kaneko \& D.B. Haidvogel. 2004. Numerical and observational estimates of Indian Ocean Kelvin wave intrusion into Lombok Strait.Geophys. Res. Lett. 31:L24307. doi:10.1029/2004GL021227.Teo, S. L. H, and B. A. Block.

Vinayachandran, P.N., Satoshilizuka, Toshio Yamagata. 2001. Indian Ocean Dipole Mode Events in an Ocean. General Circulation Model Deep-sea Research II. Special Topic Volume "Physical Oceanography of the Indian Ocean during the WOCE period.

Wells, N. 1986. The Atmosphere and Ocean: A Physical Introduction. Taylor and Francis Ltd. London, England.

Wyrtki, K. 1961. The Physical Oceanography of South East Asian Waters. Naga Report Vol. 2.University California Press.La Jolla. CA.

Wyrtki, K. 1962. The Upwelling in the Region Between Java and Australia During the South-East Monsoon. Aust. J. Mar. Freshwater Res. 13: 217-225.

Yoder, J.A \& M.A. Kennely. 2003. Seasonal and ENSO variability in global ocean phytoplankton chlorophyll derived from 4 years of SeaWiFS measurements. Global Biogeochem. Cycles 17 (4):1112. doi:10.1029/2002GB001942.

Zhou, L., R. Murtugudde \& M. Jochum. 2008. Dynamics of the intraseasonal oscillations in the Indian Ocean South Equatorial Current. J. Phys. Oceanogr. 38: 121-132. 
APPENDIX 1. SEASURFACE TEMPERATURE $\left({ }^{\circ} \mathrm{C}\right)$

\begin{tabular}{|c|c|c|c|c|c|c|c|c|c|c|}
\hline Month/Year & 2003 & 2004 & 2005 & 2006 & 2007 & 2008 & 2009 & 2010 & 2011 & 2012 \\
\hline JAN & 28.71 & 28.74 & 28.79 & 28.46 & 28.75 & 29.07 & 28.89 & 28.82 & 27.14 & 28.45 \\
\hline FEB & 28.70 & 28.78 & 29.27 & 28.90 & 29.21 & 28.15 & 28.95 & 29.69 & 27.79 & 28.59 \\
\hline MAR & 28.74 & 28.62 & 29.92 & 29.22 & 28.85 & 28.38 & 28.80 & 30.06 & 28.52 & 28.41 \\
\hline APR & 29.12 & 29.06 & 29.02 & 28.93 & 28.71 & 28.82 & 29.04 & 29.76 & 28.91 & 27.76 \\
\hline MAY & 28.48 & 28.49 & 28.58 & 28.28 & 28.40 & 27.95 & 28.73 & 29.22 & 29.00 & 27.79 \\
\hline JUN & 28.36 & 27.89 & 28.32 & 27.82 & 28.01 & 27.49 & 28.60 & 28.75 & 28.43 & 27.13 \\
\hline JUL & 27.49 & 27.31 & 27.59 & 26.80 & 27.45 & 27.12 & 27.90 & 27.96 & 27.24 & 26.97 \\
\hline AUG & 26.68 & 26.83 & 27.18 & 26.83 & 27.17 & 26.73 & 27.44 & 28.04 & 26.52 & 26.21 \\
\hline SEP & 26.68 & 26.51 & 27.10 & 25.30 & 26.54 & 26.81 & 27.02 & 27.98 & 25.91 & 26.12 \\
\hline ОСТ & 26.94 & 26.94 & 27.27 & 26.53 & 26.72 & 27.04 & 27.31 & 28.42 & 26.61 & 26.85 \\
\hline NOV & 27.23 & 27.35 & 27.76 & 27.28 & 27.80 & 27.39 & 27.82 & 27.76 & 27.52 & 27.65 \\
\hline DEC & 27.76 & 28.01 & 28.04 & 27.47 & 28.01 & 27.64 & 28.43 & 27.33 & 28.71 & 28.36 \\
\hline Average & 27.91 & 27.88 & 28.24 & 27.65 & 27.97 & 27.72 & 28.24 & 28.65 & 27.69 & 27.52 \\
\hline
\end{tabular}

APPENDIX 2. SEA SURFACE CHLOROPHYLL-A $\left(\mathrm{mg} / \mathrm{m}^{3}\right)$

\begin{tabular}{|c|c|c|c|c|c|c|c|c|c|c|}
\hline Month/ & 2003 & 2004 & 2005 & 2006 & 2007 & 2008 & 2009 & 2010 & 2011 & 2012 \\
\hline JAN & 41 & & & 0.095665 & & & & 0.089036 & 0.100078 & \\
\hline FEB & & 091927 & 0.092764 & & & & & 0.094746 & 0.120068 & \\
\hline MAR & 100406 & 0.099662 & 0.102694 & 0.107927 & 0.115231 & 0.118879 & 0.102694 & 0.098838 & 0.089598 & 838 \\
\hline APR & & & 0.12 & & 0.123 & 0.13 & & 0.09 & 0.10 & \\
\hline MAY & 425 & 0.11 & 0.11 & 2465 & 0.142623 & 0.164948 & 0.11 & 0.094876 & 973 & 876 \\
\hline JUN & 140861 & 0.117679 & 0.133027 & 0.204909 & 0.153808 & 0.229598 & & & 0.16 & \\
\hline JUL & 231081 & 0.160188 & 0.145616 & 0.22037 & 0.188517 & 0.229598 & 0.145616 & 0.130637 & 0.219898 & 30637 \\
\hline AUG & 0.242109 & 0.215547 & 0.195531 & 0.290956 & 0.2314 & 0.257737 & & & & \\
\hline SEP & 273 & 0.208452 & 0.160019 & & 0.30 & & & & 0.24 & \\
\hline OCT & 163689 & 0.153638 & 0.156938 & 0.295359 & 0.244013 & 0.151344 & 0.156938 & 0.099439 & 0.24739 & 0.199439 \\
\hline NOV & 0.119966 & 0.131355 & 0.122987 & 0.247477 & 0.111305 & 0.104006 & 0.122987 & 0.112619 & 0.113544 & 0.112619 \\
\hline DEC & 0.090324 & 0.089448 & 0.109099 & 0.146191 & 0.091133 & 0.077718 & 0.109099 & 0.083859 & 0.087965 & 0.083859 \\
\hline Average & 0.143424 & 0.131817 & 0.128279 & 0.194929 & 0.159423 & 0.153881 & 0.126604 & 0.104504 & 0.152662 & 0.125338 \\
\hline
\end{tabular}




\section{APPENDIX 3. NUMBER OF TRIPS}

Number of Trip of Tuna Longline Trip (frequency)

\begin{tabular}{|c|c|c|c|c|c|c|c|c|c|c|}
\hline Month/Year & 2003 & 2004 & 2005 & 2006 & 2007 & 2008 & 2009 & 2010 & 2011 & 2012 \\
\hline JAN & 27 & 25 & 90 & 7 & 365 & 242 & 62 & 109 & 35 & 41 \\
\hline FEB & 19 & 26 & 131 & 12 & 224 & 102 & 57 & 92 & 27 & 32 \\
\hline MAR & 20 & 24 & 71 & 8 & 160 & 92 & 40 & 124 & 25 & 36 \\
\hline APR & 11 & 36 & 86 & 4 & 99 & 81 & 37 & 94 & 31 & 40 \\
\hline MAY & 16 & 25 & 125 & 9 & 50 & 43 & 33 & 57 & 35 & 39 \\
\hline JUN & 20 & 26 & 117 & 137 & 56 & 114 & 79 & 112 & 26 & 43 \\
\hline JUL & 9 & 25 & 103 & 57 & 96 & 57 & 92 & 93 & 26 & 45 \\
\hline AUG & 4 & 23 & 87 & 53 & 137 & 29 & 67 & 67 & 29 & 32 \\
\hline SEP & 8 & 12 & 76 & 44 & 63 & 55 & 57 & 103 & 54 & 24 \\
\hline OCT & 14 & 15 & 62 & 24 & 59 & 69 & 41 & 85 & 30 & 33 \\
\hline NOV & 7 & 14 & 41 & 40 & 123 & 56 & 50 & 38 & 37 & 49 \\
\hline DEC & 9 & 30 & 88 & 189 & 179 & 139 & 79 & 103 & 43 & 41 \\
\hline Amount & 164 & 281 & 1077 & 584 & 1611 & 1079 & 694 & 1077 & 398 & 455 \\
\hline \multicolumn{11}{|c|}{ Number of Trip of Gillnet (frequency) } \\
\hline Month/Year & 2003 & 2004 & 2005 & 2006 & 2007 & 2008 & 2009 & 2010 & 2011 & 2012 \\
\hline JAN & 53 & 17 & 33 & 19 & 59 & 17 & 1 & 13 & 12 & 3 \\
\hline FEB & 39 & 42 & 19 & 8 & 33 & 15 & 0 & 5 & 5 & 10 \\
\hline MAR & 27 & 70 & 14 & 11 & 25 & 23 & 2 & 2 & 1 & 5 \\
\hline APR & 10 & 21 & 29 & 17 & 52 & 3 & 5 & 5 & 3 & 2 \\
\hline MAY & 116 & 31 & 36 & 30 & 32 & 21 & 19 & 9 & 3 & 7 \\
\hline JUN & 72 & 51 & 31 & 105 & 43 & 109 & 27 & 1 & 40 & 14 \\
\hline JUL & 204 & 105 & 34 & 151 & 60 & 93 & 23 & 2 & 12 & 26 \\
\hline AUG & 184 & 116 & 57 & 107 & 79 & 77 & 55 & 4 & 15 & 28 \\
\hline SEP & 119 & 86 & 21 & 108 & 160 & 91 & 27 & 2 & 30 & 27 \\
\hline OCT & 141 & 74 & 27 & 129 & 152 & 47 & 42 & 4 & 36 & 13 \\
\hline $\mathrm{NOV}$ & 44 & 34 & 14 & 186 & 141 & 16 & 20 & 5 & 13 & 6 \\
\hline DEC & 26 & 28 & 14 & 211 & 56 & 3 & 14 & 0 & 7 & 1 \\
\hline Amount & 1035 & 675 & 329 & 1082 & 892 & 515 & 235 & 52 & 177 & 142 \\
\hline \multicolumn{11}{|c|}{ Number of Trip of Troll Line (frequency) } \\
\hline Month/Year & 2003 & 2004 & 2005 & 2006 & 2007 & 2008 & 2009 & 2010 & 2011 & 2012 \\
\hline JAN & 0 & 0 & 13 & 32 & 36 & 18 & 27 & 98 & 78 & 19 \\
\hline FEB & 0 & 0 & 18 & 37 & 22 & 12 & 29 & 162 & 115 & 51 \\
\hline MAR & 0 & 0 & 23 & 37 & 11 & 25 & 47 & 184 & 111 & 36 \\
\hline APR & 0 & 0 & 20 & 41 & 30 & 30 & 85 & 169 & 156 & 133 \\
\hline MAY & 0 & 0 & 17 & 27 & 13 & 43 & 95 & 234 & 175 & 97 \\
\hline JUN & 0 & 0 & 17 & 16 & 24 & 46 & 126 & 261 & 333 & 175 \\
\hline JUL & 0 & 0 & 17 & 13 & 30 & 50 & 109 & 264 & 150 & 147 \\
\hline AUG & 0 & 0 & 17 & 17 & 31 & 30 & 111 & 164 & 171 & 130 \\
\hline SEP & 0 & 0 & 5 & 15 & 20 & 28 & 99 & 80 & 147 & 118 \\
\hline OCT & 0 & 0 & 4 & 4 & 6 & 41 & 94 & 152 & 115 & 93 \\
\hline NOV & 0 & 0 & 17 & 14 & 38 & 14 & 74 & 83 & 76 & 75 \\
\hline DEC & 0 & 0 & 20 & 11 & 25 & 13 & 44 & 76 & 72 & 47 \\
\hline Amount & 0 & 0 & 188 & 264 & 286 & 350 & 940 & 1927 & 1699 & 1121 \\
\hline
\end{tabular}

Total Number of Trips by Gear

\begin{tabular}{|c|c|c|c|c|c|c|c|c|c|c|}
\hline TUNAS OF FISHING GEARS & 2003 & 2004 & 2005 & 2006 & 2007 & 2008 & 2009 & 2010 & 2011 & 2012 \\
\hline Trips of Longline & 164 & 281 & 1077 & 584 & 1611 & 1079 & 694 & 1077 & 398 & 455 \\
\hline Trips of Gillnet & 1035 & 675 & 329 & 1082 & 892 & 515 & 235 & 52 & 177 & 142 \\
\hline Trips of Troll Line & 0 & 0 & 188 & 264 & 286 & 350 & 940 & 1927 & 1699 & 1121 \\
\hline Amount & 1199 & 956 & 1594 & 1930 & 2789 & 1944 & 1869 & 3056 & 2274 & 1718 \\
\hline
\end{tabular}




\section{APPENDIX 4. CACTHES}

Total Landing of Yellowfin Tuna $(\mathrm{kg})$

\begin{tabular}{lrrrrrrrrrr}
\hline Month/Year & 2003 & 2004 & 2005 & 2006 & 2007 & 2008 & 2009 & 2010 & 2011 & 2012 \\
\hline JAN & 1,254 & 66,128 & 131,709 & 6,255 & 82,878 & 107,797 & 21,699 & 58,970 & 67,262 & 128,820 \\
FEB & 0 & 27,557 & 134,554 & 22,988 & 52,619 & 54,669 & 16,876 & 95,455 & 47,778 & 71,722 \\
MAR & 0 & 28,221 & 175,948 & 35,350 & 32,598 & 34,681 & 18,859 & 156,963 & 66,066 & 44,837 \\
APR & 4,836 & 59,675 & 183,615 & 30,525 & 24,341 & 37,649 & 26,059 & 144,781 & 94,964 & 44,847 \\
MAY & 14,540 & 39,247 & 148,770 & 29,455 & 15,807 & 37,070 & 44,984 & 164,770 & 85,769 & 107,933 \\
JUN & 23,702 & 90,009 & 183,898 & 39,559 & 65,514 & 111,189 & 109,464 & 258,132 & 66,383 & 262,100 \\
JUL & 14,331 & 63,981 & 171,166 & 126,785 & 59,420 & 56,053 & 73,287 & 279,396 & 99,235 & 216,723 \\
AUG & 12,533 & 59,649 & 100,702 & 99,223 & 88,757 & 26,077 & 57,823 & 105,972 & 51,253 & 138,583 \\
SEP & 19,850 & 25,026 & 45,235 & 88,760 & 41,711 & 25,387 & 42,458 & 53,186 & 60,818 & 124,320 \\
OCT & 48,302 & 65,876 & 60,721 & 43,687 & 34,320 & 45,834 & 54,571 & 138,001 & 90,531 & 161,194 \\
NOV & 16,980 & 50,337 & 39,211 & 80,005 & 66,423 & 15,390 & 40,699 & 136,522 & 129,456 & 171,321 \\
DEC & 21,761 & 65,996 & 119,546 & 75,250 & 118,883 & 40,913 & 43,656 & 125,725 & 209,923 & 202,462 \\
\hline Amount & 178,089 & 641,702 & $1,495,075$ & 677,842 & 683,271 & 592,709 & 550,435 & $1,717,873$ & $1,069,438$ & $1,674,862$ \\
\hline
\end{tabular}

APPENDIX 5. CPUE (Standar Longline)

CPUE of Yellowfin Tuna (Standar Long Line): kilograms/trips

\begin{tabular}{|c|c|c|c|c|c|c|c|c|c|c|}
\hline Month/Year & 2003 & 2004 & 2005 & 2006 & 2007 & 2008 & 2009 & 2010 & 2011 & 2012 \\
\hline JAN & 16 & 1,574 & 180 & 292 & 968 & 389 & 241 & 268 & 538 & 2,045 \\
\hline FEB & 0 & 405 & 189 & 138 & 801 & 424 & 196 & 369 & 325 & 771 \\
\hline MAR & 0 & 300 & 166 & 166 & 1,629 & 248 & 212 & 506 & 482 & 582 \\
\hline APR & 230 & 1,047 & 134 & 237 & 1,360 & 330 & 205 & 540 & 500 & 256 \\
\hline MAY & 110 & 701 & 166 & 290 & 836 & 346 & 306 & 549 & 403 & 755 \\
\hline JUN & 258 & 1,169 & 533 & 306 & 1,115 & 413 & 472 & 690 & 166 & 1,130 \\
\hline JUL & 67 & 492 & 319 & 686 & 1,111 & 280 & 327 & 778 & 528 & 994 \\
\hline AUG & 67 & 429 & 359 & 2,186 & 625 & 192 & 248 & 451 & 238 & 729 \\
\hline SEP & 156 & 255 & 172 & 1,741 & 443 & 146 & 232 & 287 & 263 & 736 \\
\hline OCT & 312 & 740 & 158 & 1,585 & 653 & 292 & 308 & 573 & 500 & 1,160 \\
\hline NOV & 333 & 1,049 & 220 & 705 & 545 & 179 & 283 & 1,084 & 1,027 & 1,318 \\
\hline DEC & 622 & 1,138 & 457 & 1,212 & 980 & 264 & 319 & 702 & 1,721 & 2,275 \\
\hline
\end{tabular}

